\title{
Nomogramy w postępowaniu terapeutycznym u chorych na raka piersi ze zmianami przerzutowymi w węźle wartowniku - przyczyny powstania, rodzaje systemów punktowych oraz ocena ich wartości klinicznej
}

\author{
Tomasz Nowikiewicz ${ }^{1}$, Wojciech Zegarski ${ }^{2}$
}

Procedura biopsji węzła wartownika (WW) u chorych z niezaawansowanym rakiem piersi pozwoliła znacznie ograniczyć nasilenie niekorzystnych następstw związanych z klasyczną limfadenektomią pachową. Obecność zmian przerzutowych w WW współistnieje u części chorych z zajęciem przez przerzuty węzłów niewartowniczych. W zależności od wielkości przerzutów stwierdzanych wWW wspomniana sytuacja kliniczna może dotyczyć od 10 do $41 \%$ przypadków. Zatem przynajmniej u około 3/5 pacjentów ze zdiagnozowanym w WW przerzutem badanie histopatologiczne usuniętych węzłów chłonnych pachy — w ramach radykalizacji leczenia operacyjnego — nie wykaże istnienia kolejnych zmian. Dostępne obecnie systemy (nomogramy) liczbowej oceny możliwości stwierdzenia przerzutów w niewartowniczych węzłach chłonnych dołu pachowego pozwalają trafnie ustalić prawdopodobieństwo ich wystąpienia. Ułatwiają tym samym podjęcie dalszych decyzji terapeutycznych.

Nomograms in therapeutic treatment of patients with breast cancer with metastatic changes in sentinel lymph node - causes, types of point systems and evaluation of their clinical value Sentinel lymph node (SLN) biopsy procedure in patients with non-advanced breast cancer made it possible to considerably reduce the intensity of unfavourable after-effects connected with classical axillary lymphadenectomy. The presence of metastatic changes in SLN coexists in some patients with metastases to non-SLN. Depending on the size of the metastases detected in SLN, the above mentioned clinical situation may affect from $10-41 \%$ of cases. Therefore in about $3 / 5^{\text {ths }}$ of patients with diagnosed SLN metastasis, histopathological examination of removed axillary lymph nodes - within the radicalization of surgical treatment, will not reveal further changes. Presently available calculation devices (nomograms) for measuring the likelihood of metastases in non-SLN of the armpit make it possible to accurately determine the probability of their occurrence. They therefore simplify further therapeutic decisions.

NOWOTWORY Journal of Oncology 2013; 63, 3: 250-256

Słowa kluczowe: rak piersi, węzeł wartownik, przerzuty węzłowe, nomogram

Key words: breast cancer, sentinel node, nodal metastases, nomogram

\section{Następstwa poprawy wykrywalności zmian nowotworowych piersi}

Najbardziej oczekiwaną i jednocześnie naturalną konsekwencją wprowadzenia narodowych programów profilaktycznych badań przesiewowych dotyczących chorób nowotworowych jest obniżenie ryzyka zgonu z przyczyn onkologicznych. Wynosi ono, w grupie w ten sposób zdiagnozowanych przypadków raka piersi u kobiet po ukończeniu 50. roku życia, około 30-32\% [1-3]. Natomiast w warunkach polskich zastosowanie skriningowych badań mammograficznych pozwoliło na wzrost możliwości wykorzystania u chorych procedur leczenia oszczędzającego

\footnotetext{
${ }^{1}$ Oddział Kliniczny Nowotworów Piersi i Chirurgii Rekonstrukcyjnej

${ }^{2}$ Katedra i Klinika Chirurgii Onkologicznej, CM UMK w Bydgoszczy

Centrum Onkologii im. prof. F. Łukaszczyka w Bydgoszczy
} 
gruczoł piersiowy (breast conserving treatment - BCT) oraz układ chłonny dołu pachowego (biopsja węzła wartownika - sentinel lymph node biopsy - SLNB) [4]. Zbyt krótki okres od wprowadzenia w naszym kraju wspomnianych badań przesiewowych (w 2004 roku) nie umożliwił jeszcze sformułowania innych wniosków dotyczących odległych wyników leczenia chorych.

Wcześniejsze wykrycie raka piersi, optymalnie w stadium przed- lub subklinicznym, wiąże się najczęściej z brakiem obecności przerzutów w regionalnym układzie chłonnym — węzłach chłonnych dołu pachowego. Ich stan, obok wielkości zmiany pierwotnej, jest najważniejszym czynnikiem prognostycznym mającym wpływ na wyniki leczenia chorych [5].

SLNB jako metoda oceny regionalnego zaawansowania choroby u chorych na raka piersi zastąpiła historycznie niezbędną do tego celu limfadenektomię pachową (axillary lymph node dissection - ALND). Leczenie oszczędzające układ chłonny dołu pachowego zastosowano w pierwszej kolejności u pacjentek bez klinicznie podejrzanych przed zabiegiem węzłów chłonnych pachy. Główną przyczyną upowszechnienia się SLNB był fakt obecności zmian węzłowych jedynie u 20-30\% chorych z cechą cNO [6, 7]. Bezpieczeństwo stosowania metody potwierdziły obserwacje Kraga i wsp. oraz innych autorów [8-11]. Ponadto dzięki wykorzystaniu usunięcia węzła wartownika (WW) u większości leczonych w ten sposób chorych nie obserwowano wystąpienia powikłań (lub ich nasilenia) charakterystycznych dla ALND.

American Joint Committee on Cancer (AJCC) wyróżnił wśród zmian przerzutowych dotyczących węzłów chłonnych izolowane komórki guza (isolated tumor cells - ITC) o wielkości do 0,2 mm, mikroprzerzuty (o wielkości większej niż 0,2 mm i nieprzekraczające $2 \mathrm{~mm}$ ) oraz przerzuty (zmiany powyżej $2 \mathrm{~mm}$ ) [12]. Z badań Pernas i wsp. wynika, iż w przypadku dodatniego wyniku oceny patologicznej WW u 40\% chorych przerzuty mogą dotyczyć także innych węzłów chłonnych dołu pachowego [13]. Natomiast u chorych z mikroprzerzutem wWW (pN1 mi) wspomniany odsetek wynosi jedynie 10-15\%. Wyniki wieloośrodkowego badania AMAROS (After Mapping of the Axilla: Radiotherapy or Surgery?) potwierdziły te spostrzeżenia [14]. Zajęcie przez przerzuty węzłów niewartowniczych w poddanym analizie materiale klinicznym dotyczyło $41 \%$ chorych z obecnym w WW makroprzerzutem oraz $18 \%$ - w przypadku mikroprzerzutów. Z kolei zdaniem Giobuina i wsp., w grupie chorych pN1 mi na raka piersi (wykrywanych najczęściej przy użyciu oznaczeń immunohistochemicznych - IHC) można spodziewać się zmian przerzutowych w pozostałych węzłach chłonnych dołu pachowego w jeszcze większym odsetku przypadków - nawet do $23 \%$ [15].

\section{Nowe problemy dotyczące niektórych aspektów biopsji węzła wartownika}

Oprócz zauważonych różnic dotyczących możliwości przerzutowania niezaawansowanego raka piersi do węzłów chłonnych pachy, Pugliese i wsp. przeanalizowali wpływ wielkości przerzutów stwierdzanych w wyniku SLNB na odległe wyniki leczenia chorych [16]. Porównanie dotyczyło grup pacjentów bez zmian węzłowych wWW (pN0), z przerzutami wykrytymi w testach IHC - pNO(i+) (chorzy z ITC oraz większość przypadków mikroprzerzutów) i pacjentów z przerzutami wWW przekraczającymi wielkość $2 \mathrm{~mm}$ (pN1). Zarówno czas przeżycia całkowitego (overall survival — OS), jak i okres przeżycia wolnego od nawrotu choroby (recurrence-free survival - RFS) nie wykazywały u chorych pN0 oraz pNO(i+) istotnych statystycznie różnic. Podobne wnioski przedstawiono także w innych badaniach $[13,15,17,18]$.

Przytoczone powyżej spostrzeżenia sprawiły, iż początkowa konieczność wykonania uzupełniającej leczenie operacyjne ALND w każdym przypadku wykrycia zmian przerzutowych wWW uległa modyfikacji. Obecnie formułowane wskazania kliniczne dotyczące dalszego postępowania terapeutycznego zależą od wielkości stwierdzanych przerzutów oraz liczby zajętych węzłów wartowniczych.

Wydaje się, iż powszechnie zaakceptowano możliwość leczenia zachowawczego w przypadku wykrycia w pojedynczym WW mikroprzerzutów lub ITC. Zgodnie z opublikowanymi zaleceniami panelu ekspertów XII Konferencji w St. Gallen (III 2011) w opisanej sytuacji nie jest wymagane wykonanie ALND [19]. Natomiast najczęściej aktualnie rozstrzyganym problemem jest próba odpowiedzi na pytanie: w których przypadkach zdiagnozowania w WW przerzutów (w tym także przekraczających wielkość $2 \mathrm{~mm}$ ) można w sposób bezpieczny dla chorego odstąpić od radykalizacji leczenia operacyjnego.

Przynajmniej częściowe rozwiązanie tego problemu przedstawiono w wynikach randomizowanego badania ACOSOG Z001 [20]. Włączono do niego chore z inwazyjnym rakiem piersi (cT1-2N0) poddane wycięciu guza pierwotnego oraz SLNB, u których ocena patologiczna wykazała obecność przerzutów wWW. Po porównaniu odległych wyników leczenia chorych zakwalifikowanych do uzupełniającej ALND oraz po wykonanej jedynie SLNB, nie stwierdzono różnic znamiennych statystycznie dotyczących zarówno OS (91,8\% vs $92,5 \%)$, jak również RFS (82,2\% vs $83,9 \%)$. Analizowane grupy pacjentek nie różniły się pod względem najważniejszych czynników klinicznych (wiek, wielkość i postać histologiczna guza, status receptorów steroidowych, obecność inwazji naczyń, stopień złośliwości histologicznej).

Grono ekspertów z St. Gallen zaakceptowało powyższą opcję terapeutyczną [19]. Ograniczono jednak możliwość zastosowania leczenia zachowawczego do przypadków 
zdiagnozowania zmian przerzutowych w maksymalnie dwóch węzłach chłonnych usuniętych podczas SLNB.

\section{Systemy statystyczne oceny ryzyka obecności zmian przerzutowych dotyczących węzłów chłonnych dołu pachowego}

Poza wykazaniem braku wpływu na obserwowane wyniki leczenia zarówno wykrycia w WW mikroprzerzutów (w porównaniu z grupą pN0), jak również rodzaju dalszego postępowania (wykonanie uzupełniającej ALND lub leczenie zachowawcze), Pugliese i wsp. zwrócili uwagę na istnienie kolejnego problemu klinicznego [16]. Pomimo uzyskania zbliżonych efektów terapeutycznych (OS, RFS) dotyczących wszystkich pacjentów pNO oraz pNO(i+) stwierdzili u części chorych pNO(i+) istotnie statystycznie wyższy odsetek przypadków nawrotu choroby w porównaniu z chorymi bez przerzutu w WW (20\% vs 4,8\%). Opisana sytuacja dotyczyła pacjentów z obecnością zmian przerzutowych w WW oraz w innych, niewartowniczych węzłach chłonnych dołu pachowego. Grupę tę autorzy wyselekcjonowali, wykonując u części spośród chorych pNO(i+) limfadenektomię pachową.

Wspomniana powyżej radykalizacja leczenia operacyjnego nie poprawiła odległych wyników leczenia, umożliwiła jednak wyodrębnienie chorych, którzy wymagają zastosowania bardziej radykalnego leczenia systemowego. Nie można zatem wykluczyć, iż postępowaniem alternatywnym do przedstawionego będzie wykorzystanie u pacjentów agresywnych schematów lekowych w ramach chemioterapii adiuwantowej, przy jednoczesnym pominięciu wykonania ALND.

Pierwsze z modeli liczbowej oceny ryzyka obecności zmian przerzutowych w węzłach chłonnych dołu pachowego opracowano przed upowszechnieniem SLNB jako jedynej metody oceny regionalnego zaawansowania procesu nowotworowego $u$ chorych na raka piersi w stopniu cN0. Wprowadzane systemy miały zatem ułatwić rozstrzygnięcie problemu ewentualnego braku zasadności wykonania limfadenektomii pachowej w najwcześniejszych stadiach choroby (z reguły sytuacja dotyczyła chorych cT1a).

Olivotto i wsp. zaproponowali model, w którym w analizie wieloczynnikowej brano pod uwagę wielkość zmiany pierwotnej, jej palpacyjność oraz obecność inwazji naczyniowej guza [21]. Autorzy stwierdzili, iż u chorych na raka piersi, ze zmianą nowotworową nieprzekraczającą $5 \mathrm{~mm}$ (bez względu na jej palpacyjność), przy jednoczesnym braku naciekania naczyń w badaniu histapatologicznym, ryzyko stwierdzenia przerzutów w dole pachowym wynosi poniżej $5 \%$. Zasugerowali, aby w takich przypadkach ograniczyć zakres niezbędnego leczenia operacyjnego do usunięcia guza wraz z marginesem makroskopowo niezmienionych tkanek (kwadrantektomia).

Nieco wcześniej Ravdin i wsp. opracowali system oceniający zasadność ALND w oparciu o analizę statystycz- ną danych klinicznych pochodzących z grupy prawie 12000 chorych po takim zabiegu operacyjnym [22]. Badania pozwoliły, podobnie jak w pierwszym przykładzie, na wyodrębnienie pacjentów z prawdopodobieństwem stwierdzenia zmian węzłowych poniżej 5\%, a także pozwalały przewidywać liczbę zajętych węzłów chłonnych pachy. Metoda miała jednak swoje ograniczenia - wymagała wykonania złożonych oznaczeń w materiale tkankowym pochodzącym z przedoperacyjnej biopsji gruboigłowej (określenie ploidii komórek guza oraz ilości komórek w fazie S).

Z kolei Gann i wsp. wykazali istotny statystycznie wpływ na możliwość powstawania zmian przerzutowych w dole pachowym takich czynników jak wiek chorej, wielkość i lokalizacja guza (kwadranty zewnętrzne piersi), stopień złośliwości histologicznej, zmiany liczby chromosomów komórek nowotworowych oraz typ przewodowy raka [23].

Proste i jednocześnie praktyczne narzędzie do oceny możliwości znalezienia przerzutów w węzłach chłonnych dołu pachowego stworzyli Martin i wsp. [24]. W ich modelu prognostycznym wzięto pod uwagę parametry kliniczne, które - zgodnie z zamierzeniem autorów — powinny być do ustalenia przed rozpoczęciem leczenia operacyjnego (wielkość i lokalizacja guza oraz jego postać histologiczna z oceną stopnia złośliwości w oparciu o system Scarffa-Blooma-Richardsona). Analiza wieloczynnikowa umożliwiła autorom przydzielenie badanych chorych do jednego z utworzonych przedziałów liczbowych określających ryzyko wystąpienia przerzutów. Uzyskane w oparciu o omawiany system wyniki w wysokim stopniu korelowały z wynikami rzeczywistymi, otrzymanymi po ALND.

\section{Nomogramy}

Omówione powyżej modele statystyczne straciły swą przydatność wraz z szerokim wykorzystaniem SLNB w leczeniu chorych z wczesnymi postaciami raka piersi. Wycięcie i ocena histopatologiczna węzła wartownika, oprócz alternatywnego dla ALND sposobu weryfikacji stopnia zaawansowania choroby, dostarczyła także nowych danych klinicznych (liczba wyciętych podczas biopsji węzłów chłonnych, odsetek węzłów zmienionych przerzutowo, obecność nacieku torebki węzła). Mogły być one użyteczne przy konstruowaniu nowych systemów liczbowej oceny możliwości stwierdzenia przerzutów w niewartowniczych węzłach chłonnych dołu pachowego.

Ze względu na sposób punktowania branych pod uwagę zmiennych oraz rodzaj przewidywanego ryzyka pojawienia się przerzutów, wśród opracowanych systemów można wyróżnić nomogramy (nomograms) oraz skale punktowe (scoring systems).

Pierwsze z nich, w oparciu o wieloczynnikową analizę regresji logistycznej, określają prawdopodobieństwo wystąpienia zdarzenia dla każdego chorego indywidualnie. Drugie oparto na związku wybranych zmiennych z okre- 
Tabela I. Nomogramy — rodzaje wykorzystywanych danych klinicznych

\begin{tabular}{|c|c|c|c|c|c|}
\hline Analizowane czynniki kliniczne & MSKCC [26] & Cambridge [27] & Stanford [28] & Mayo [29] & Ljubljana $^{1}[30]$ \\
\hline Wiek chorego & - & - & - & tak & - \\
\hline Wielkość guza (pt) & tak & - & tak & tak & tak \\
\hline Palpacyjność guza & - & - & - & - & - \\
\hline Postać histologiczna & tak & - & - & - & - \\
\hline Stopień złośliwości - G & - & tak & - & - & - \\
\hline Naciekanie naczyń & tak & - & tak & - & tak \\
\hline Wieloogniskowość & tak & - & - & - & - \\
\hline Status receptora ER & tak & - & - & - & - \\
\hline Liczba usuniętych WW & - & - & - & - & - \\
\hline Liczba WW(+) & tak & - & - & tak & tak \\
\hline Liczba WW(-) & tak & - & - & tak & tak \\
\hline Naciekanie torebki WW & - & - & - & tak & - \\
\hline Wielkość przerzutu w WW & - & tak & tak & tak & tak \\
\hline Metoda wykrycia przerzutu & tak & - & - & - & - \\
\hline$W W(+) / W W(+)+W W(-)$ & - & tak & - & - & - \\
\hline Dół pachowy — ocena USG & - & - & - & - & tak \\
\hline — punkt odcięcia & $\leq 10 \%$ & $\leq 10 \%$ & $\leq 10 \%$ & $\leq 10 \%$ & $<10 \%$ \\
\hline
\end{tabular}

Użyte skróty: PT — wielkość guza w badaniu histopatologicznym, ER — receptor estrogenowy, WW - węzeł wartownik, WW(+) — WW z przerzutem, WW(-) — WW bez przerzutu, USG — badanie ultrasonograficzne

${ }^{1}$ uwzględniono czynniki kliniczne dla nomogramu stosowanego przy rutynowym wykorzystaniu badania śródoperacyjnego WW

śloną wartością punktową. Otrzymany wynik końcowy, po uwzględnieniu punktu odcięcia (threshold), pozwala na przyporządkowanie badanego przypadku do grupy niskiego lub wysokiego prawdopodobieństwa wystąpienia zdarzenia - obecności przerzutu [25].

W 2003 roku przedstawiono dane dotyczące pierwszego z możliwych obecnie do wykorzystania nomogramów [26]. W opracowanym w Memorial Sloan-Kettering Cancer Center w Nowym Jorku systemie (MSKCC Nomogram) uwzględniono osiem parametrów klinicznych: wielkość patologiczna i wieloogniskowość guza, postać histologiczna oraz stopień złośliwości histologicznej nowotworu, obecność naciekania naczyń, status receptora estrogenowego, liczba usuniętych podczas SLNB węzłów chłonnych (liczba węzłów z obecnością przerzutów i węzłów bez zmian przerzutowych, metoda wykrycia przerzutu wWW). Pojawiające się szybko następne systemy punktowe wykorzystywały również inne zmienne, także w różnych konfiguracjach — szczegółowe dane przedstawiono w tabeli I [26-30] i tabeli II [31-33].

Wprowadzenie kolejnych systemów prognostycznych poprzedziła ocena podstawowych kryteriów dotyczących ich wartości prognostycznej - cech kalibracji, zdolności dyskryminacji, poziomu wyników fałszywie ujemnych oraz użyteczności klinicznej skal.

Właściwa kalibracja (wzorcowanie) systemu punktowego świadczy o odpowiednim dopasowaniu liczebności zdarzeń obserwowanych i przewidywanych w testowanym modelu. Ocena kalibracji badanego systemu przeprowa- dzana jest najczęściej w oparciu o testowanie goodnes-of-fit (GOF — dokładność pasowania) Hosmera i Lemeshowa [34]. Uzyskanie niskich wartości $\chi^{2}$ sugeruje dobrą kalibrację badanej metody. W sposób graficzny test Hosmera i Lemeshowa przedstawiają krzywe kalibracji.

Dyskryminacja testu punktowego określa jego zdolność do różnicowania przewidywanej i obserwowanej ilości zdarzeń, czyli rozróżnianie pomiędzy dwoma zbiorami zdarzeń w oparciu o szacowane prawdopodobieństwo wystąpienia zdarzenia [35]. Analiza dyskryminacyjna rozstrzyga zatem, w oparciu o które spośród ocenianych zmiennych można w optymalny sposób dokonać podziału zbioru zdarzeń na podgrupy. Graficzną interpretacją statystyki, używanej najczęściej do oceny zdolności dyskryminacji badanych systemów, jest krzywa ROC (receiver operating characteristic curve) oraz pole pod krzywą ROC (AUC - area under the ROC curve). O lepszej dyskryminacji analizowanego modelu punktowego świadczy uzyskanie obliczanych wartości liczbowych jak najbardziej zbliżonych do 1,0 (górna granica przedziału: punkt odcięcia - 1,0) oraz możliwość wykreślenia krzywej ROC w jak najmniejszej odległości od tej wartości. Optymalne wartości AUC to przedział liczbowy 0,81-0,9, natomiast wartości AUC możliwe do zaakceptowania mieszczą się w zakresie 0,7-0,8.

Oczekiwany odsetek wyników fałszywie ujemnych testu (FN - false negative rate) został zdefiniowany na poziomie mniejszym lub równym 5\% (wartość dopuszczalna $\leq 10 \%$ ). Określa on zdolność ocenianego systemu do trafnego wy- 
Tabela II. Skale punktowe — rodzaje wykorzystywanych danych klinicznych

\begin{tabular}{|c|c|c|c|}
\hline Analizowane czynniki kliniczne & Tenon [31] & MDA [32] & Saidi [33] \\
\hline Wielkość guza (pt) & $\begin{array}{c}0 \text { pkt: } \leq 10 \mathrm{~mm} \\
1,5 \text { pkt: } 11-20 \mathrm{~mm} \\
3 \text { pkt: }>20 \mathrm{~mm}\end{array}$ & $\begin{array}{l}0 \mathrm{pkt}: \leq 10 \mathrm{~mm} \\
1 \mathrm{pkt}:>10 \mathrm{~mm}\end{array}$ & $\begin{array}{l}1 \mathrm{pkt}: \leq 10 \mathrm{~mm} \\
2 \mathrm{pkt}:>10 \mathrm{~mm}\end{array}$ \\
\hline Palpacyjność guza & - & - & $\begin{array}{l}1 \text { pkt: tak } \\
0 \text { pkt: nie }\end{array}$ \\
\hline Naciekanie naczyń & - & $\begin{array}{l}1 \text { pkt: TAK } \\
0 \text { pkt: NIE }\end{array}$ & $\begin{array}{l}1 \text { pkt: tak } \\
0 \text { pkt: nie }\end{array}$ \\
\hline Liczba usuniętych WW & - & -2 pkt: $\geq 3$ & - \\
\hline Naciekanie torebki WW & - & - & $\begin{array}{l}1 \text { pkt: tak } \\
0 \text { pkt: nie }\end{array}$ \\
\hline Wielkość przerzutu w WW & $\begin{array}{l}2 \mathrm{pkt}:>2 \mathrm{~mm} \\
0 \mathrm{pkt}: \leq 2 \mathrm{~mm}\end{array}$ & $\begin{array}{l}2 \mathrm{pkt}:>2 \mathrm{~mm} \\
0 \mathrm{pkt}: \leq 2 \mathrm{~mm}\end{array}$ & - \\
\hline$W W(+) / W W(+)+W W(-)$ & $\begin{array}{c}0 \text { pkt: } \leq 0,5 \\
1 \text { pkt: }>0,5 \mathrm{i}<1 \\
2 \text { pkt: }=1\end{array}$ & - & - \\
\hline — zakres punktacji & od 0 do $7 \mathrm{pkt}$ & od -2 do 4 pkt & od 0 do 4 pkt \\
\hline — punkt odcięcia & $\leq 3,5 \mathrm{pkt}$ & $\leq 0 \mathrm{pkt}$ & $\leq 2 \mathrm{pkt}$ \\
\hline
\end{tabular}

dzielenia grupy chorych z niskim prawdopodobieństwem obecności przerzutów w węzłach chłonnych niewartowniczych.

Wysoka użyteczność kliniczna systemu oznacza jego zdolność do identyfikacji jak największej odsetkowo grupy pacjentów z przewidywanym brakiem zajęcia węzłów niewartowniczych lub prawdopodobieństwem stwierdzenia w nich przerzutów nieprzekraczającym poziomu $10 \%$.

\section{Nomogramy - ocena}

Głównym zadaniem, którego wykonanie ułatwiło zastosowanie nomogramów, jest możliwość wyodrębnienia z grupy chorych z obecnością zmian przerzutowych w WW, pacjentów wymagających uzupełniającej leczenie operacyjne limfadenektomii pachowej. Trafność i skuteczność takiego postępowania terapeutycznego pozwalają ocenić (oprócz metod statystycznych wymienionych powyżej), także uzyskane wyniki odległe leczenia chorych, wśród nich odsetek wznów miejscowych w dole pachowym.

Wysoką przydatność nomogramu MSKCC do oceny grupy 1960 chorych na raka piersi poddanych SLNB, ze stwierdzeniem przerzutów w WW, przedstawiła Park i wsp. [36]. Zastosowanie systemu umożliwiło autorom zakwalifikowanie 287 pacjentów do dalszego leczenia zachowawczego. W czasie średnio 23-miesięcznego okresu obserwacji chorych zaobserwowano w tej grupie 2,0\% nawrotów choroby dotyczących dołu pachowego (6/287). W grupie pacjentów poddanych uzupełniającej ALND odsetek ten wyniósł 0,4\%.

Uzyskane przez Park wyniki dotyczące liczby wznów pachowych są zbliżone do przedstawionych w wieloośrodkowym badaniu klinicznym AMAROS [14, 37]. Ich poziom, zaobserwowany u pacjentek po ALND, wykonanej po SLNB z pozytywnym wynikiem oceny patologicznej WW, wyniósł
1,2\%. Był więc nieznamiennie statystycznie niższy niż opisany powyżej, mimo zdecydowanie innej strategii leczenia chorych z takim samym stanem zaawansowania choroby - pN1a(sn).

Z kolei Hwang i wsp., oceniając w tym samym aspekcie wartość kliniczną skali MD Anderson Cancer Center (MDA — [32]), nie stwierdzili żadnego przypadku nawrotu w węzłach chłonnych pachy [38]. Badanie dotyczyło 196 chorych z przerzutem w WW, leczonych zachowawczo, ze średnim okresem obserwacji wynoszącym niespełna 2,5 roku.

Wartość kliniczna nomogramu MSKCC — jako najwcześniej opracowanego z omawianych systemów punktowych — została oceniona dotychczas w największej liczbie opracowań. Dotyczy to badań pochodzących z innych ośrodków w Stanach Zjednoczonych [28, 29, 32, 33, 39], analiz wykonanych w oparciu o populacje chorych na raka piersi inne niż wykorzystana przez jego autorów oraz porównań z nowo wprowadzanymi narzędziami statystycznymi. Jednocześnie nomogram MSKCC, mimo iż najstarszy spośród obecnie stosowanych, został opracowany przy wykorzystaniu danych klinicznych największej liczebnie, jak do tej pory, grupy pacjentek.

Odpowiednia (chociaż nie zawsze najwyższa) przydatność systemu MSKCC do oceny prawdopodobieństwa obecności przerzutów w węzłach niewartowniczych, u chorych niezamieszkujących obszaru USA, uzyskała potwierdzenie przez innych autorów. W badaniach pochodzących z ośrodków europejskich — Pal i wsp. (Wlk. Brytania) [27], D’Eredita i wsp. (Włochy) [40], Perhavec i wsp., Zgajnar i wsp. (Słowenia) [30,41], Barranger i wsp., Coutant i wsp. (Francja) [31, 42], van la Parra i wsp. (Holandia) [43], Gur i wsp. (Turcja) [44], Coufal i wsp. (Czechy) [45], północnoafrykańskich — Hidar i wsp. (Tunezja) [46] oraz azjatyckich — Sasada i wsp. 
(Japonia) [47], Chen i wsp. (Chiny) [48] stwierdzono możliwą do zaakceptowania wartość AUC. Jednocześnie w części wspomnianych opracowań zaprezentowano własne rozwiązania dotyczące omawianego problemu klinicznego, charakteryzujące się nieco wyższą zdolnością dyskryminacji (odpowiednie pozycje z piśmiennictwa wymieniono w tabelach I i II).

Wykorzystanie nomogramów może ułatwić wybór dalszego postępowania terapeutycznego również w bardzo wybiórczo wyselekcjonowanych grupach chorych. Pomimo powszechnej akceptacji braku konieczności wykonywania uzupełniającej ALND w przypadku wykrycia w pojedynczym WW mikroprzerzutów lub ITC [19], systemy punktowe mogą dodatkowo dostarczyć przekonujących argumentów dla słuszności takiej opcji leczenia. Szczegółowa analiza przydatności klinicznej wybranych skal (łącznie dziewięciu) przedstawiona przez Coutanta i wsp. wykazała, iż posiadają one wysoką użyteczność kliniczną, także w przypadku oceny pacjentów pN1mi(sn) [25]. Zdaniem autorów najwyższą wartość AUC uzyskał system Tenon (0,81), z obserwowanym jednocześnie niskim odsetkiem wyników fałszywie ujemnych $-2,9 \%$. Jego użycie pozwoliło ponadto na zakwalifikowanie $85 \%$ badanych chorych do grupy niskiego ryzyka obecności przerzutów w węzłach niewartowniczych. Akceptowalną wartość AUC zaobserwowano jeszcze w przypadku dwóch innych nomogramów - MSKCC orazStanford (odpowiednio: 0,72 oraz 0,73), przy poziomie wyników FN rzędu $3,5 \%$ oraz $2,2 \%$. Pozostałe oceniane modele nie posiadały odpowiedniej przydatności w analizowanej grupie chorych (AUC $<0,7$ ).

Natomiast zdaniem D’Eredity i wsp. [40] oraz Houvenaeghela i wsp. [49], analizujących wartość kliniczną Tenon score oraz MSKCC nomogram, jedynie pierwszy z wymienionych modeli statystycznych posiada odpowiednią zdolność dyskryminacji w grupie chorych z mikroprzerzutem w WW (wartość AUC odpowiednio: 0,734 oraz 0,595). Autorzy drugiego badania proponują jednocześnie użycie własnego systemu punktowego [49].

Nomogramy mogą znaleźć zastosowanie także przy szacowaniu prawdopodobieństwa zajęcia przez przerzuty węzłów powartowniczych u chorych poddanych chemioterapii neoadjuwantowej. Analizując dane 132 pacjentów, którzy otrzymali leczenie systemowe poprzedzające SLNB, Gimbergues i wsp. wykorzystali do tego celu trzy modele [50]. W przypadku dwóch z nich wartość AUC osiągnęła pożądany poziom (odpowiednio: MSKCC - 0,542; MDA -0,716; Tenon - 0,778).

Uzupełnieniem wyników zastosowania nomogramów w przedstawionych analizach klinicznych są wnioski podane przez Silversteina i wsp. [51]. Autorzy stwierdzają, iż niezbędnym warunkiem wykorzystania w praktyce klinicznej systemów punktowych oceny prawdopodobieństwa obecności zmian przerzutowych w węzłach niewartowni- czych jest wyczerpujące przedstawienie leczonym chorym uzyskanych tą drogą informacji. Dotyczy to również omówienia wszystkich alternatywnych metod postępowania terapeutycznego.

\section{Nomogramy - podsumowanie}

Opisane systemy prognostyczne uzyskały pozytywną ocenę jako narzędzia przydatne do wyodrębnienia grupy chorych o podwyższonym ryzyku zajęcia węzłów chłonnych niewartowniczych. Określenie, z możliwym do zaakceptowania prawdopodobieństwem, obecności zmian przerzutowych w kolejnych węzłach chłonnych dołu pachowego przy wyjściowo jednoczesnym zajęciu WW pozwala przeciwdziałać wystąpieniu gorszych, odległych wyników leczenia. W wybranych przypadkach także bez konieczności kontynuacji leczenia operacyjnego.

Upowszechnianie się określania nowych narzędzi prognozowania wyników leczenia chorych (oznaczanie ekspresji genów, określanie podtypów molekularnych [52] oraz biologicznych raka piersi [53], wyniki badań immunohistochemicznych: oznaczanie TIMP-1, indeksu Ki-67 [54]) stanie się niewątpliwie przyczyną opracowania nowych systemów punktowych.

\section{Dr n. med. Tomasz Nowikiewicz}

Katedra i Klinika Chirurgii Onkologicznej

Oddział Kliniczny Nowotworów Piersi i Chirurgii Rekonstrukcyjnej

CM UMK w Bydgoszczy

Centrum Onkologii im. prof. F. Łukaszczyka

ul. Romanowskiej 2, 85-796 Bydgoszcz

e-mail: tomasz.nowikiewicz@gmail.com

Otrzymano: 10 września $2012 r$

Przyjęto: 12 grudnia $2012 \mathrm{r}$.

\section{Piśmiennictwo}

1. Jacson VP. Screening mammography; controversies and headlines. $R a$ diology 2002; 225: 323-326.

2. Spillane AJ, Kennedy CW, Gillett DJ i wsp. Screen-detected breast cancer compared to symptomatic presentation: an analysis of surgical treatment and end-points of effective mammographic screening. ANZ J Surg 2001; 71: 398-402.

3. Tabar L, Fagerberg G, Duffy SW i wsp. Update of the Swedish Two County Program of Mammographic Screening for Breast Cancer. Radiol Clin North Am 1992; 30: 187-210.

4. Nowikiewicz T, Mierzwa T, Zegarski W i wsp. Wpływ populacyjnego programu profilaktyki i wczesnego wykrywania raka piersi na możliwość zastosowania leczenia oszczędzającego węzły chłonne dołu pachowego - procedura biopsji węzła wartownika. W: Profilaktyka raka piersi i raka szyjki macicy. Mierzwa T, Zegarski W (red.). Bydgoszcz: Centrum Onkologii; 2012, 31-38.

5. Donegan WL. Tumor-related prognostic factors for breast cancer. $C A$ Cancer Clin J 1997; 47: 28-51.

6. Kiluk JV, Ly QP, Santillan AA i wsp. Erratum to: Axillary recurrence rate following negative sentinel node biopsy for invasive breast cancer: long-term follow-up. Ann Surg Oncol 2010; 17: 552-557.

7. Haagensen CD, Bodian C. A personal experience with Halsted's radical mastectomy. Ann Surg 1984; 199: 143-150.

8. Krag DN, Anderson SJ, Julian TB i wsp. Sentinel-lymph-node resection compared with conventional axillary-lymph-node dissection in clinically node-negative patients with breast cancer: overall survival findings from the NSABP B-32 randomised phase 3 trial. Lancet Oncol 2010; 11: 927-933. 
9. Zavagno G, De Salvo GL, Scalco G i wsp. A randomized clinical trial on sentinel lymph node biopsy versus axillary lymph node dissection in breast cancer: results of the Sentinella/GIVOM trial. Ann Surg 2008; 247: 207-213.

10. Kim T, Giuliano AE, Lyman GH. Lymphatic mapping and sentinel lymph node biopsy in early-stage breast carcinoma: a metaanalysis. Cancer 2006; 106: 4-16.

11. Mansel RE, Fallowfield L, Kissin M i wsp. Randomized multicenter trial of sentinel node biopsy versus standard axillary treatment in operable breast cancer: the ALMANAC Trial. J Natl Cancer Inst 2006; 98: 599-609.

12. Greene $\mathrm{FL}$, American Joint Committee on Cancer, American Cancer Society, AJCC. Cancer Staging Manual, 6th ed. New York: Springer-Verlag; 2002.

13. Pernas $\mathrm{S}, \mathrm{Gil} \mathrm{M}$, Benítez $\mathrm{A}$ i wsp. Avoiding axillary treatment in sentinel lymph node micrometastases of breast cancer: a prospective analysis of axillary or distant recurrence. Ann Surg Oncol 2010; 17: 772-777.

14. Straver ME, Meijnen P, van Tienhoven G i wsp. Sentinel node identification rate and nodal involvement in the EORTC 10981-22023 AMAROS trial. Ann Surg Oncol 2010; 17: 1854-1861.

15. Giobuin SM, Kavanagh DO, Myers E i wsp. The significance of immunohistochemistry positivity in sentinel nodes which are negative on haematoxylin and eosin in breast cancer. Eur J Surg Oncol 2009; 35: 1257-1260.

16. Pugliese M, Stempel M, Patil S i wsp. The clinical impact and outcomes of immunohistochemistry-only metastasis in breast cancer. Am J Surg 2010; 200: 368-373.

17. Carvalho MJ, Dias MF, Silva TS i wsp. Breast cancer patients with micrometastases in sentinel lymph nodes: differences considering additional metastatic lymph nodes. Eur J Gynaecol Oncol 2009; 30: 631-634.

18. Takei H, Suemasu K, Kurosumi M i wsp. Recurrence after sentinel lymph node biopsy with or without axillary lymph node dissection in patients with breast cancer. Breast Cancer 2007; 14: 16-24.

19. Goldhirsch A, Wood WC, Coates AS i wsp. Strategies for subtypes-dealing with the diversity of breast cancer: highlights of the St Gallen International Expert Consensus on the Primary Therapy of Early Breast Cancer 2011. Ann Oncol 2011; 22: 1736-1747.

20. Giuliano AE, Hunt KK, Ballman KV i wsp. Axillary dissection vs no axillary dissection in women with invasive breast cancer and sentinel node metastasis. A randomized clinical trial. JAMA 2011; 305: 569-575.

21. Olivotto IA, Jackson JS, Mates D i wsp. Prediction of axillary lymph node involvement of women with invasive breast carcinoma: a multivariate analysis. Cancer 1998; 83: 948-955.

22. Ravdin PM, De Laurentiis M, Vendely $\mathrm{T}$ i wsp. Prediction of axillary lymph node status in breast cancer patients by use of prognostic indicators. J Nat/ Cancer Inst 1994; 86: 1771-1775.

23. Gann PH, Colilla SA, Gapstur SM i wsp. Factors associated with axillary lymph node metastasis from breast carcinoma: descriptive and predictive analyses. Cancer 1999; 86: 1511-1519.

24. Martin C, Cutuli B, Velten M. Predictive model of axillary lymph node involvement in women with small invasive breast carcinoma: axillary metastases in breast carcinoma. Cancer 2002; 94: 314-322.

25. Coutant C, Olivier C, Lambaudie E i wsp. Comparison of models to predict nonsentinel lymph node status in breast cancer patients with metastatic sentinel lymph nodes: a prospective multicenter study. J Clin Oncol 2009; 27: 2800-2808.

26. Van Zee KJ, Manasseh DM, Bevilacqua JL i wsp. A nomogram for predicting the likelihood of additional nodal metastases in breast cancer patients with a positive sentinel node biopsy. Ann Surg Oncol 2003; 10: 1140-1151.

27. Pal A, Provenzano E, Duffy SW i wsp. A model for predicting non-sentinel lymph node metastatic disease when the sentinel lymph node is positive. Br J Surg 2008; 95: 302-309.

28. Kohrt HE, Olshen RA, Bermas HR i wsp. New models and online calculator for predicting non-sentinel lymph node status in sentinel lymph node positive breast cancer patients. BMC Cancer 2008; 8: 66 .

29. Degnim AC, Reynolds C, Pantvaidya G i wsp. Nonsentinel node metastasis in breast cancer patients: assessment of an existing and a new predictive nomogram. Am J Surg 2005; 190: 543-550.

30. Perhavec A, Perme MP, Hocevar M i wsp. Ljubljana nomograms for predicting the likelihood of non-sentinel lymph node metastases in breast cancer patients with a positive sentinel lymph node. Breast Cancer Res Treat 2010; 119: 357-366.

31. Barranger $E$, Coutant $C$, Flahault A i wsp. An axilla scoring system to predict non-sentinel lymph node status in breast cancer patients with sentinel lymph node involvement. Breast Cancer Res Treat 2005; 91: 113-119.
32. Hwang RF, Krishnamurthy S, Hunt KK i wsp. Clinicopathologic factors predicting involvement of non-sentinel axillary nodes in women with breast cancer. Ann Surg Oncol 2003; 10: 248-254.

33. Saidi RF, Dudrick PS, Remine SG i wsp. Nonsentinel lymph node status after positive sentinel lymph node biopsy in early breast cancer. Am Surg 2004; 70: 101-105.

34. Hosmer DW, Taber S, Lemeshow S. The importance of assessing the fit of logistic regression models: a case study. Am J Public Health 1991; 81: 1630-1635.

35. Hanley JA, McNeil BJ.The meaning and use of the area under a receiver operating characteristic (ROC) curve. Radiology 1982; 143: 29-36.

36. Park J, Fey JV, Naik AM i wsp. A declining rate of completion axillary dissection in sentinel lymph node-positive breast cancer patients is associated with the use of a multivariate nomogram. Ann Surg 2007 245: 462-468.

37. Rutgers EJ, Meijnen P, Bonnefoi $\mathrm{H}$. Clinical trials update of the European Organization for Research and Treatment of Cancer Breast Cancer Group. Breast Cancer Res 2004; 6: 165-169.

38. Hwang RF, Gonzales-Angulo AM, Yi M i wsp. Low locoregional failure rates in selected breast cancer patients with tumor-positive sentinel lymph nodes who do not undergo completion axillary dissection. Cancer 2007; 110: 723-730.

39. Dauphine CE, Haukoos JS, Vargas MP i wsp. Evaluation of three scoring systems predicting non sentinel node metastasis in breast cancer patients with a positive sentinel node biopsy. Ann Surg Onco/ 2007: 14: 1014-1019.

40. D'Eredita G, Troilo VL, Giardina C i wsp. Sentinel lymph node micrometastasis and risk of non-sentinel lymph node metastasis: validation of two breast cancer nomograms. Clinical Breast Cancer 2010; 10:445-451.

41. Zgajnar J, Perhavec A, Hocevar M i wsp. Low performance of the MSKCC nomogram in preoperatively ultrasonically negative axillary lymph node in breast cancer patients. J Surg Oncol 2007; 96: 547-553.

42. Coutant C, Rouzier R, Fondriener E i wsp. Validation of the Tenon breast cancer score for predicting non-sentinel lymph node status in breast cancer patients with sentinel lymph node metastasis: a prospective multicenter study. Breast Cancer Res Treat 2009; 113: 537-543.

43. van la Parra RFD, Ernst MF, Bevilacqua JLB i wsp. Validation of a nomogram to predict the risk of nonsentinel lymph node metastases in breast cancer patients with a positive sentinel node biopsy: validation of the MSKCC breast nomogram. Ann Surg Oncol 2009; 16: 1128-1135.

44. Gur AS, Unal B, Ozbek U i wsp. Validation of breast cancer nomograms for predicting the non-sentinel lymph node metastases after a postive sentinel lymph node biopsy in a multi-center study. Eur J Surg Oncol 2010; 36: 30-35.

45. Coufal O, Pavlík T, Fabian P i wsp. Predicting non-sentinel lymph node status after positive sentinel biopsy in breast cancer: what model performs the best in a Czech population? Pathol Oncol Res 2009; 15: 733-740.

46. Hidar S, Harrabi I, Benregaya L i wsp. Validation of nomograms to predict the risk of non-sentinel lymph node metastases in North African Tunisian breast cancer patients with sentinel node involvement. Breast 2011; 20: 26-30.

47. Sasada T, Murakami S, Kataoka Ti wsp. Memorial Sloan-Kettering Cancer Center Nomogram to predict the risk of non-sentinel lymph node metastasis in Japanese breast cancer patients. Surg Today 2012; 42: 245-249.

48. Chen K, Zhu L, Jia W i wsp. Validation and comparison of models to predict non-sentinel lymph node metastasis in breast cancer patients. Cancer Sci 2012; 103: 274-281.

49. Houvenaeghel G, Bannier M, Nos C i wsp. Non sentinel node involvement prediction for sentinel node micrometastases in breast cancer: nomogram validation and comparison with other models. Breast 2012; 21: 204-209.

50. Gimbergues $P$, Abrial C, Durando X i wsp. Clinicopathological factors and nomograms predicting nonsentinel lymph node metastases after neoadjuvant chemotherapy in breast cancer patients. Ann Surg Oncol. 2009; 16: 1946-1951.

51. Silverstein MJ, Lagios MD, Recht A i wsp. Image-detected breast cancer: state of the art diagnosis and treatment. J Am Coll Surg 2005; 201: 586-597.

52. Prat A, Perou CM. Deconstructing the molecular portraits of breast cancer. Mol Oncol 2011; 5: 5-23.

53. Cheang MC, Chia SK, Voduc D i wsp. Ki67 index, HER2 status, and prognosis of patients with luminal B breast cancer. J Nat I Cancer Inst 2009; 101: 736-750.

54. Tvedskov TF, Bartels A, Jensen MB i wsp. Evaluating TIMP-1, Ki67, and HER2 as markers for non-sentinel node metastases in breast cance patients with micrometastases to the sentinel node. APMIS 2011 119: 844-852. 